\title{
Reduction of Communication Uncertainty for COVID-19 Community Service Program Students Universitas Sebelas Maret
}

\author{
Haris Annisari Indah Nur Rochimah; Prahastiwi Utari; Sri Hastjarjo \\ Department of Communication, Faculty of Social and Political Science, Universitas Sebelas Maret, Indonesia \\ http://dx.doi.org/10.18415/ijmmu.v8i12.3279
}

\begin{abstract}
The COVID-19 pandemic that has hit the world since the beginning of 2020 has certainly had a major impact on human interaction. The world of education is one of those affected by restrictions on the learning process and also other policies, including community service activities carried out by students, namely Kuliah Kerja Nyata (KKN). Universitas Sebelas Maret is a state university which at the beginning of the COVID-19 Pandemic was a pioneer in holding the COVID-19 community service program. Student KKN in its work program holds activities related to preventing the transmission of COVID-19 in the community as well as food and economic security. What is different from KKN is usually the COVID-19 KKN, students have to go out on their own in the community without being in groups. They hold KKN work programs in their respective neighborhoods while maintaining health protocols. This study will review the reduction of communication uncertainty that occurs to students of the COVID-19 Community service program at Universitas Sebelas Maret where they have to build relationships independently with the surrounding community where they feel that they have left their homes for a long time while studying in Solo. There is a sense of communication uncertainty that occurs in students when they have to interact and build communication with the community, therefore, this study uses the Uncertainty Reduction Theory (URT) perspective which was pioneered by Charler Berger and Richard Calabrese. This research is a qualitative research using a descriptive type of research and with the conclusion of an active, passive, and interactive description of the strategy for reducing communication uncertainty for COVID-19 students.
\end{abstract}

Keywords: Student Community Service Program; Uncertainty; URT; COVID-19 Community Service Program; COVID-19 Pandemic

\section{Introduction}

The COVID-19 pandemic that has hit most countries in the world has had a significant impact on people's behavior patterns. The change in behavior pattern is of course due to activity restrictions in order to suppress the transmission of the virus. Restricting community activities in several aspects of life is a policy taken by the Indonesian government in order to suppress the spread of the corona virus. Coronavirus is a group of viruses that can infect both animals and humans. Several types of coronavirus are known to cause respiratory tract infections, ranging from coughing and colds to more severe ones, such as Middle East Respiratory Syndrome (MERS) and Severe Acute Respiratory Syndrome (SARS). In 
the process of spreading, this new type of Coronavirus called Corona virus Disease-2019 (COVID-19) tends to be fast, namely through droplets of saliva and droplets that come out of the mouth of people who are talking, coughing, running a cold or sneezing (WHO, 2020).

Since the appearance of the first positive case of COVID-19 in Indonesia on March 2, 2020, the number of confirmed positive cases and deaths has continued to increase. The COVID-19 pandemic has a systemic impact and disrupts almost all aspects of human life, including in the field of higher education. Globally, the United Nation Educational, Scientific and Cultural Organization (UNESCO) reported that on April 20, 2020, 191 countries had closed education units with 1,575,270,054 affected students. In Indonesia, the COVID-19 pandemic affected 646,192 education units, 68,801,708 students, and 4,183,591 educators ranging from early childhood education to higher education, special education, vocational education, community education, courses and religious education (Kemendikbud, 2020).

Universitas Sebelas Maret (UNS) as one of the higher education institutions in Indonesia has also implemented several policies related to the activities of the tri dharma of higher education during the pandemic. Since the implementation of an Extraordinary Event (KLB) in Surakarta City which was set on March 13, 2020, on March 16, 2020, the Chancellor of UNS issued circular No. 1480/UN27/HK/2020 concerning self-awareness, preparedness and anticipatory measures to prevent the spread of COVID Infections -19 in the Universitas Sebelas Maret environment. The circular appealed to the entire UNS academic community to implement the implementation of clean and healthy living.

In terms of lecture activities, the form of offline lectures is changed to online lectures. Likewise, for community service activities, seminars and work visits out of town, the chancellor called for it to be postponed until the situation is declared conducive. In its development, the status of the outbreak as well as data on the transmission of COVID-19 in the city of Surakarta shows that there has not been a decrease in the number of infected patients and has actually increased quite significantly as has happened in Indonesia in general. In the current adaptation phase of new habits, community activities for areas with green and yellow zones are starting to be gradually opened, including for universities, while still prioritizing health protocols. This is certainly very influential on the activities of the tri dharma of higher education which are carried out within the Universitas Sebelas Maret, one of which is the community service program carried out by students, namely the Kuliah Kerja Nyata (KKN).

The status of the outbreak as well as data on COVID-19 transmission in the city of Surakarta shows that there has been no decrease in the number of infected patients and has actually increased quite significantly as has happened in Indonesia in general. In the current adaptation phase of new habits, community activities for areas with green and yellow zones are starting to be opened gradually, including for universities, while still prioritizing health protocols.

This is certainly very influential on the activities of the tri dharma of higher education which are carried out within the Universitas Sebelas Maret, one of which is the community service program carried out by students, namely the Kuliah Kerja Nyata (KKN). The status of the outbreak as well as data on COVID-19 transmission in the city of Surakarta shows that there has been no decrease in the number of infected patients and has actually increased quite significantly as has happened in Indonesia in general. In the current adaptation phase of new habits, community activities for areas with green and yellow zones are starting to be gradually opened, including for universities, while still prioritizing health protocols.

This is certainly very influential on the activities of the tri dharma of higher education which are carried out within the Universitas Sebelas Maret, one of which is the community service program carried out by students, namely the Kuliah Kerja Nyata (KKN). community activities for areas with green and yellow zones began to be opened gradually, including for universities, while still prioritizing health protocols. This is certainly very influential on the activities of the tri dharma of higher education which 
are carried out at the Universitas Sebelas Maret, one of which is the Community service program carried out by students, namely the Real Work Lecture (KKN). Community activities for areas with green and yellow zones began to be opened gradually, including for universities, while still prioritizing health protocols. This is certainly very influential on the activities of the tri dharma of higher education which are carried out at the Universitas Sebelas Maret, one of which is the community service program carried out by students, namely the Kuliah Kerja Nyata (KKN).

Universitas Sebelas Maret in an effort to work together to deal with the COVID-19 outbreak in Indonesia, referring to the policy of the Ministry of Education and Culture (Kemdikbud) through the Directorate General of Higher Education (Ditjen Dikti) has also committed to participate in mitigating the COVID-19 pandemic in the thematic KKN program COVID-19. Following up on these efforts and as an implementation of the tri dharma of higher education through the policy of the independent campus, free learning, the directorate General of Higher Education of the Ministry of Education and Culture collaborates with the COVID-19 Handling Task Force, the National Disaster Management Agency (BNPB), the Association of Indonesian Medical Education Institutions (AIPKI), the Medical Student Senate Association. Indonesia (ISMKI) and with the support of various stakeholders, organized the community service program related to COVID-19.

The output of this program, held in conjunction with the COVID-19 community service program. This community service program is expected to increase the synergy of students, communities, universities, government, and stakeholders (to the regional level) in an effort to work together in handling COVID-19, especially to provide education and increase awareness of the importance of changing behavior to adapt to new habits for the community. This KKN is expected to encourage students' concrete contributions as agents of change in society to create a productive and safe society in the face of a pandemic. KKN is part of the college KKN program that can be appreciated with credit recognition (credits) and certificates of community service. KKN participants who are students from various fields can carry out in their respective areas of residence.

There is an adjustment in the way of implementing KKN which currently must be carried out online, so it is interesting for us to see how students prepare themselves to carry out the COVID-19 thematic KKN independently in their respective areas of residence online. It is not allowed to have direct interaction and communicate directly with the public due to the COVID-19 pandemic. Of course, this new concept raises some interesting problems to research. From the results of the pre-research survey, it was found some information from students regarding their first experience of carrying out KKN COVID-19. Many students are hesitant to join the COVID-19 community service program because they feel insecure, anxiety because they have to do the work program alone, which was previously a group. Even though the work program is carried out at their residence in their area of origin, they still feel insecure to carry out their COVID-19 community service program independently.

The obligation to carry out work programs while still complying with health protocols by not holding mass crowds requires students to use online media, namely social media in disseminating their work programs. Several students who were willing to be interviewed through a pre-survey of this research via google form stated that according to them the COVID-19 community service program in their own village was a lot of challenges if it was done alone, especially as in his experience, including immigrants in the village, he found it difficult to carry out work programs because he did not know who he was. Who's in the village? He felt stressed and depressed, because he was confused about running his own work program in a new place (FN, from Tegal Regency). Constraints related to the character of the community in each different region are also a challenge for students. The factor that not all students are able to do an activity alone is also a problem in itself, especially students who have problems with not being confident in communicating (KA, from Magelang Regency). 
During the implementation of the COVID-19 community service program, in addition to feeling anxious and insecure, students must be alone in implementing their programs, the results of the initial survey in the field, it turns out that they also have to do it online and offline. This of course causes anxiety in students whether I can run work programs in the area where I live online using social media or offline? How should they convey their work program with social media which is not necessarily the local community is familiar with social media? Will the messages that will be conveyed be conveyed to the public? How to arrange the message that will be conveyed through social media? These are the anxiety felt by students in the context of the online way. They also feel anxieties offline, how they then negotiate their identity in the environment and the local community. Even though they carry it out in their own area of residence, for students who have lived outside the city for a long time, they are studying to study at a university, to return to enter the midst of society requires re-adaptation.

They must rebuild their self-confidence to interact again with the community in the planned COVID-19 KKN work program. Even though they carry it out in their own area of residence, for students who have lived outside the city for a long time, they are studying to study at a university, to return to enter the midst of society requires re-adaptation. They must rebuild their self-confidence to interact again with the community in the planned COVID-19 KKN work program. Even though they carry it out in their own area of residence, for students who have lived outside the city for a long time, they are studying to study at a university, to return to the midst of society requires adaptation. They must rebuild their selfconfidence to interact again with the community in the planned COVID-19 KKN work program.

The condition where students must first ask permission from the "Rukun Tetangga" (RT) and also the community around them to carry out KKN will cause problems about uncertainty in themselves and also their communication partners. The greater the sense of not knowing each other and feeling alienated and the less we know about other people, the greater the uncertainty and sometimes anxiety and fear that the student feels. In order to reduce the uncertainty of KKN students and also the community who will be involved in the program, the right strategy is needed so that the communication can be effective and useful. Uncertainty is a doubt about a relationship whereas in any interaction.

\section{Literature Review}

Interpersonal skills are needed in the success of a service program or community service, communication styles to deal with the community must be adapted to their different personalities (Haidar et al., 2020). Communication that is established between humans often experiences various obstacles. Barriers in any communication will certainly affect the effectiveness of the communication process (Rismayanti, 2018). This often causes anxiety and uncertainty in the process of interpersonal communication. So that the anxiety and uncertainty that occurs should be managed properly by the parties involved in the communication process (Farisi et al., 2020).

Student anxiety in the process of building interaction with the community is certainly influenced by their self-concept (Kholisin, 2014). The COVID-19 community service program student at Universitas Sebelas Maret is no exception. Anxiety and worries that occur to COVID-19 community service students at Universitas Sebelas Maret need to be reduced so that they do not become a nuisance, both for themselves and the interactions that are built with the community targeting community service program.

Previously, research on anxiety, communication and self-concept of KKN students had been reviewed by several previous studies. Among them, regarding the effect of emotional intelligence on public speaking anxiety, and the effect of self-concept and emotional intelligence on public speaking anxiety (Kholisin, 2014). 
Furthermore, research on the influence of interpersonal communication on the adjustment of students at Bhayangkara University, Jakarta Raya who are conducting Kuliah Kerja Nyata (KKN) in 2019 on self-adjustment in the KKN environment. The results show that the higher the value of interpersonal skills, the higher the value of self-adjustment abilities in students who are currently studying. take a real job lecture (Bangun et al., 2021)

In this study, the communication uncertainty that occurred to the COVID-19 community service program students at Universitas Sebelas Maret will use the perspective of Uncertainty Reduction Theory (URT). URT or also known as Uncertainty Reduction Theory was pioneered by Charler Berger and Richard Calabrese in 1975 and aims to explain how communication is used to reduce uncertainty between strangers who are talking to each other for the first time (Dianna \& Lailiyah, 2019).

West and Turner explained that URT has basic assumptions, namely: a) When communicating interpersonally with people they do not know, a person experiences uncertainty, b) Uncertainty can trigger cognitive stress because uncertainty is an unwelcome situation, c) When two people who are not mutually exclusive know to meet and have to be involved in a conversation, then they will start predictions or estimates regarding information from the other person, d) Interpersonal communication is a situation that develops through stages. The initial stage where the individual begins the interaction, the second stage is the personal stage where personal or individual expressions begin to be expressed, and the final stage when a person continues the relationship or even breaks the relationship (West \& Turner, 2018).

Berger states that there are two uncertainties experienced by a person as follows: a) Cognitive uncertainty, namely initial thoughts that contain expectations about the desired behavior of a person for the continuation of the relationship, and b) Behavioral uncertainty, namely thoughts that arise in a person about the possibility to understand someone's behavior more deeply (Febriani \& Iqbal, 2015). In accordance with URT, uncertainty reduction strategies that may be used include: a) Passive strategy, which is an information search activity with reactivity searching in the form of observation, in this case the target community for KKN can be local community leaders such as RT officials and pay attention to their responses, as well as disinhibition searching is a passive action against people who will get information when that person is in a state as it is and not in a formal state. b) Active strategy, is an effort to actively ask others about someone they want to get information about before interacting directly with the target. c) Interactive strategy in the form of self-disclosure activities and being open with others and expecting others to do the same (Anazuhriah, 2019).

Uncertainty is a person's inability to predict or explain the behavior, feelings, attitudes or values of others (Primasari, 2014). Efforts to interact directly will be disrupted by the uncertainty of communication participants, especially the COVID-19 community service students at Universitas Sebelas Maret who have to interact with the community targeting KKN. The existence of uncertainty also means that the students are anxious about the community groups they have to meet when they run their work programs. Where as in any interaction, to achieve the best communication results, trust is needed for both parties.

URT states that no matter how close an individual is to another individual, their relationship must begin with a sense of alienation and uncertainty (Anazuhriah, 2019), as well as the COVID-19 Community service program at Universitas Sebelas Maret. Re-entering theneighborhood after being abroad for a long time as a student and having to "ask permission" to local officials to enter the target groups of the work program such as Pembinaan Kesejahteraan Keluarga (PKK) womens will create a feeling of uncertainty. 
This uncertainty arises because of the limited information faced by students. Therefore, they will collect information about other people to predict the attitudes and behavior of others (Antheunis et al., 2012). In addition, in order to achieve the desired goals, a person must be able to use the information he has about other people, the more information obtained about other people, the attractiveness will increase and the need for information will decrease in other words, uncertainty will decrease (Littlejohn et al., 2017).

Communication is considered as an important role in the process of reducing uncertainty in a person's self (Gibbs et al., 2011). Things that one must do in reducing uncertainty include the following: a) Verbal communication, which shows that the more verbal communication is done, the less uncertainty, b) Non-verbal affiliation expression, which is a factor in the uncertainty reduction process in the form of eye contact, head nodding, gestures, and other non-verbal expressions means that the more non-verbal communication is expressed, the uncertainty will be reduced, c) Information search, namely high uncertainty increases information seeking activities, d) Proximity, namely the level of closeness to an information content in conversations will increase when uncertainty is low (West \& Turner, 2018). The use of uncertainty reduction theory can explain forms of uncertainty and the processes and strategies used by COVID-19 community service students at Universitas Sebelas Maret in reducing uncertainty.

\section{Method}

This research is a qualitative research using descriptive research type. Burhan Bungin explained that qualitative research is a research process that has a deeper level of criticism than all research processes carried out (Bungin, 2007). Morrisan explained that in general descriptive research is a research method that has the aim of explaining specifically on an event by describing or describing research (Malestha \& Kusumaningtyas, 2020). While the type used in this research is a case study. Case studies are used to provide an understanding of something that attracts attention, social processes that occur, concrete events, or experiences of people who are the background of a case (Prihatsanti et al., 2018).

The technique of selecting informants in research uses the technique of purposive sampling involving seven informants with different KKN locations. WND students are from Medan, ND students are from Padang, DL students are from Bali, AND students are from Lampung, AF students are from Bontang, AR students are from Aceh and HN students are from Pontianak. Purposive sampling is a technique for determining informants in research with certain considerations aimed at making the selected data more representative (Sugiyono, 2013). The criteria for informants in this study were students who carried out the COVID-19 community service program at Universitas Sebelas Maret who did it independently and had long migrated to Solo so that they felt there was anxiety and uncertainty when they had to enter the community around where they lived.

The data in this study are divided into two types, according to the source, namely primary and secondary sources. Primary data comes from sources that provide data directly from the first hand or are original sources (Arikunto, 2006). While secondary data is research data obtained by researchers indirectly through intermediary media (Syafnidawaty, 2020).

Furthermore, the researchers conducted data analysis using the Miles and Huberman Punch data analysis technique in the form of data reduction, data presentation and conclusion drawing in which researchers compared various data from various sources and then selected data that were considered to be used as definite data in this study (Anazuhriah, 2019). As well as data triangulation which is a technique to test the validity of the data and the validity of the research results by using information outside the data to be compared with data obtained in the field (Kriyantono, 2012). 


\section{Results and Discussion}

This study focuses on the process of reducing uncertainty carried out by COVID-19 community service students at Universitas Sebelas Maret through their interpersonal communication. This process is seen from the point of view of the theory of reducing uncertainty in itself with certain strategies and the processes they undergo according to their respective conditions. Students of the COVID-19 community service program at Universitas Sebelas Maret reduce their uncertainty with the aim of achieving the goal of communicating in the implementation of the KKN work program that is arranged to run smoothly. The following are the results of research that researchers obtained from COVID-19 community service students at Universitas Sebelas Maret through the interview process and various supporting data from selected informants.

\section{Uncertainty of COVID-19 Community Service Program Students}

There is an environment that is developing and undergoing changes, such as the presence of new residents, the structure of the area where KKN students live, which also undergoes changes, plus they have been migrating to Solo for a long time. Makes students experience anxiety, lack of confidence, and experience uncertainty when they will mingle and interact with the community around where they live. Moreover, they will join the PKK group and others in order to carry out their independent community service program work program. As stated by one of the following informants:

"I felt awkward and confused when I first had to ask permission from the RT to conduct a community service program in the area around where I live. hehe I'm a new resident and rarely go home, because of this pandemic I just went home and never interacted with my neighbors. especially since I'm a homebody. I'm worried that my program won't be optimal because I don't feel confident doing it in the PKK RT group. I'm afraid that they won't be accepted and they're not enthusiastic about my program. I'm ashamed if they can't accept me hehe Honestly, I never imagined before that I had to do KKN alone. I hope the KKN will be in groups " (Interview with WND, March 4, 2021)

From the WND statement, it can be seen that worries are not accepted even though they live in their own environment, making the student experience anxiety, fear, and uncertainty. Is he accepted? How to ask permission from community leaders and whether the work program can run smoothly, how should she join the group of PKK women who during this pandemic still cannot be active offline but online. Of course, ND also feels the higher concern:

"So when I gave the proposal to the RT, I was asked to go to the village for permission first. Because I didn't know I didn't know, I finally invited my mother, who is used to it and already knows the village people. Hehehe, I was teased, why is my mother still with me? already a student? but I really don't feel confident and I'm worried that the permit will be complicated if I don't invite my mother. Because I haven't been back to Padang for a long time so I'm like a new person at home, hehehappens to be my proker about online marketing workshops for mothers PKK in the context of food and economic security in the midst of the COVID-19 pandemic (Interview with ND, March 4, 2021)

Similar concerns with WND and ND also experienced by DL. The student who did the independent community service in Denpasar Bali, felt anxious when he had to come alone to the tourism management association in the Denpasar area. He is worried that the work program proposal regarding the workshop on the application of health protocols in tourist areas will not be accepted.

"Asking for complete papers and asking if not in groups? So it's true that the existence of my own $\mathrm{KKN}$ is being questioned, Ms. Hehehe, maybe it's strange that KKN is my own. that makes me even less confident" (Interview with DL, March 5, 2021) 
Not different from the previous three informants, AND as the fourth informant also expressed the same concern. Worried when he met a group of farmers in his village. AND said, "Actually, they accepted me, Ms. when I was allowed to hold community service activities that involved farmers in their groups, then maybe because they thought my KKN program was the same as the previous KKN program, I felt that they proposed a lot of different activities. I can't do it myself. Here I feel that my communication with the chairperson has missed communication, so what I say is not fully understood, but they still think that KKN students will be able to do a lot of activities. This makes me worried and worried, Ms".

The concerns felt by the informants which then lead to communication uncertainty between KKN students and the target community. The uncertainty experienced by independent KKN students occurs because of the lack and limited information about the community they will meet and also the public's ignorance about the independent KKN program carried out by students.

In addition to cognitive uncertainty, there are data that researchers have obtained from the field that show behavioral uncertainty related to how far the behavior of other people in certain situations is (Febriani \& Iqbal, 2015). Informants have an estimate of the behavior of the people they meet, especially regarding their trust and openness to the independent KKN program.

"Sometimes the people I meet show that they are not enthusiastic about my program, it seems they don't believe it even though I have used my alma mater coat and also brought a letter from campus, so they feel careful too with me who yesterday conveyed socialization about COVID-19, maybe because there are several cases where there are individuals who take advantage of this pandemic to commit crimes so that when I myself without any group came to convey their program, it was not immediately open" (Interview with AF, March 6, 2021)

This type of uncertainty is an uncertainty that occurs because students bring up estimates that cause concern in their minds because of the uncertainty itself. The students guessed for themselves how they would receive feedback from the community.

\section{Uncertainty Reduction Process}

Reducing uncertainty in oneself is not an activity that just happens, but must go through the process of reducing uncertainty itself. Berger and Calabrese state that there are two processes of reducing uncertainty, namely the proactive process and the retroactive process (Anazuhriah, 2019). The proactive process is a process of reducing uncertainty which is at the stage when a person is thinking before communicating with others. In other words, the proactive process is a process where students make predictions and alternative communication steps and predict what responses may be heard or received before interacting with the target or community. Through interviews that researchers conducted with informants, a proactive process was carried out by students to reduce uncertainty.

"After I got my permit, I continued to do field observations first, Ms., by asking whether my program had ever been carried out in the area. At that time, I asked my brother, then he said there was no program about online marketing workshops for women. Now, I feel like I have an argument later when I meet the PKK management, Ms. Hehehe, so I have to look for information first for my program, Ms. So as not to impress my KKN activities carelessly" (Interview with ND, March 4, 2021)

As Berger argues, a proactive process occurs when people think about the choices they might make (West \& Turner, 2018). In this case, COVID-19 KKN students who carry out KKN independently and go directly to the target community. The data shows that students tend to think in advance what 
actions they will show or take before meeting the target community of KKN. This is an effort where students want to build an interaction with the community that has been adapted to the conditions of each KKN area.

Process retroactive, namely the process when a person's efforts or behavior after meeting the interlocutor. This process is a process that is in the post-interaction stage, where someone will try to explain how the interaction works and the behavior and response choices that are received and sent to the interlocutor he just met.

"Yes, ma'am, when I said I was a KKN student from UNS, Mr. RT didn't immediately say yes, he was worried because when there was a pandemic and the case was going up, so he reminded me that my KKN activities should not become the spread of the covid virus in the area, and I said I will do it according to the prokes and also permission to enter the wag of PKK women" (Interview with WND, March 4, 2021)

The students explained how the interlocutors, in this case the target community leaders or groups, behaved after communicating with them. There is an explanation of the theory regarding the processretroactivity in the informant's statement, where the informant is in the process when he describes the behavior and attitudes of his interlocutor after interacting with him. This active uncertainty reduction process is a form of analysis of the situation experienced by the students and the community as the target of the KKN. This also confirms that interpersonal communication to reduce uncertainty is indeed carried out by COVID-19 KKN students and has a significant impact on the continuity and smoothness of the COVID-19 KKN they work program.

\section{Uncertainty Reduction Strategy}

Uncertainty reduction is driven by the motivation or desire of students to reduce the uncertainty within themselves towards the target communities of the COVID-19 community service program. Even though the students felt anxious and worried about how their initial interaction with the community targeted for community service program would be, they realized that they had to interact with community leaders or groups that were targeted by the COVID-19 community service program.

"Because we still have to ask permission ma'am to do this KKN, although alone and in our own region we have to contact several parties and try to convey our programs so that they can be accepted" (Interview with AR, March 6, 2021)

Passive strategy is a strategy used to reduce uncertainty by finding out about other people not by direct contact (Febriani \& Iqbal, 2015). Researchers found that what they used was a passive strategy, namely a strategy in which students did not actively seek information but through finding out who the characters would meet or how the groups that would be the target of the community Service would be. This was done by the students so that they were familiar with the terrain when carrying out the COVID19 community service program.

Another type of strategy that researchers found is an active strategy. An active strategy is a strategy that involves an active effort to find out people who want information but without having to meet and face the person directly(Antheunis et al., 2012). This is done by the students by making sure to return to the target community regarding whether the figures or community groups targeted for KKN accept the student work program or not. This was explained by DL, one of the informants. 
"I made sure whether my program was in accordance with the needs of the surrounding community or not, at that time there were things that were not appropriate, Ms. then I discussed with the apparatus there and finally I also got input from them" (Interview with DL on March 5, 2021)

This strategy allows students to do research or search for information without having to take the risk of adjusting when it comes to meeting face-to-face and talking to new people. Furthermore, the strategy that is widely used by COVID-19 KKN students in reducing uncertainty is an interactive strategy. Interactive strategies are also used by students where this strategy is in the form of interacting directly with people who have been looking for information before. This strategy applies a business that involves the acquisition or acquisition of information through direct interaction in the form of greetings, introductions and then asking the target audience (Anazuhriah, 2019).

"So when I introduced myself I also tried to ask some things related to the local residents and also whether I should be involved in RT activities or I walk alone. Thank God the RT is very welcome and willing to help me convey my program to local residents" (Interview with HN on March 7, 2021)

COVID-19 KKN students interact with the aim of approaching community leaders or groups that are targeted for KKN. The statements and conditions of the students have been validated by the WND. In an interview on March 4, 2021, WND conveyed that the concerns and uncertainty felt by students when building relationships with the target community for community service program were a natural thing in the implementation of the COVID-19 community service program, as well as various efforts made to reduce these concerns and uncertainties. the establishment of good communication with residents and also the smooth running of their COVID-19 KKN work program activities.

\section{Conclusion}

Students experience uncertainty in interpersonal communication in conducting independent community service, namely COVID-19 KKN in the form of cognitive uncertainty where students have distrust when they have to introduce themselves to the community, and feel they are in a situation that is so limited by various health protocols during the COVID-19 pandemic. more or less affect the interaction and communication between students and students targeting KKN.

There is also behavioral uncertainty experienced by students because they make predictions about behaviorthe target community figure or group in the initial encounter that raises concern in his mind because of the uncertainty it self. In it, there is a process where students reduce uncertainty, including a proactive process in which students think about the communication options they might make for the smooth implementation of their COVID-19 KKN work program. They tend to think in advance what actions they might take and demonstrate to achieve good communication in the implementation of KKN. A retroactive process in which students are in the process of describing an analysis of the situation, behavior and attitudes of students after interacting with the community for the first time.

Uncertainty can be reduced in the independent community service program, students apply the first active strategy, namely students conduct research or search for information without having to risk adapting to the target community directly, including by finding out their complete identity and position. Second, a passive strategy in which students seem to be silent and do not actively interact and choose to observe the target community of KKN. Third, an interactive strategy where students interact with the aim of approaching, and ensuring that the community can accept their work program and can be involved in it. In accordance with the communication competencies that students have, students use interactive strategies to reduce the uncertainty they feel. 


\section{Suggestions and Recommendations}

Suggestions and recommendations that researchers provide for UP KKN LPPM UNS is able to make policies that are more adaptive to the latest current conditions regarding the implementation of KKN. Communication competence should be needed by every student who does KKN both independently and in groups. Therefore, the provision of KKN is not only about how to technically prepare proposals and good reports but also how to soft skills regarding communication are also held quite intensively. For the next research, the researcher suggests to expand to a wider and deeper realm. Hopefully this research is useful.

\section{References}

Anazuhriah. (2019). Pengurangan Ketidakpastian Melalui Komunikasi Interpersonal Remaja Panti Asuhan. Jurnal Common, 3(1), 34-51.

Antheunis, M. L., Schouten, A. P., Valkenburg, P. M., \& Peter, J. (2012). Interactive Uncertainty Reduction Strategies and Verbal Affection in Computer-Mediated Communication. Communication Research, 39(6), 757-780. https://doi.org/10.1177/0093650211410420

Arikunto, S. (2006). Prosedur Penelitian Suatu Pendekatan Praktik. Rieneka Cipta.

Bangun, M., Muzzamil, F., \& Andreas, N. (2021). EFEK KOMUNIKASI INTERPERSONAL PENYESUAIAN DIRI PADA MAHASISWA UNIVERSITAS BHAYANGKARA JAKARTA RAYA YANG MENJALANI KULIAH KERJA NYATA. Jurnal Syntax Admitation, Vol 2(No.2).

Bungin, B. (2007). Penelitian Kualitatif, Komunikasi, Ekonomi, Kebijakan Publik, dan Ilmu Sosial lainnya. Kencana Prenada Media Group.

Dianna, A. M., \& Lailiyah, N. (2019). Komunikasi orang tua untuk mengurangi ketidakpastian pada anak retardasi mental. Interaksi Online, 7(4), 1-12. https://ejournal3.undip.ac.id/index.php/interaksionline/article/view/24763/22157

Farisi, L. Al, Wiyono, T., \& Nurhuda, M. (2020). Pengelolaan Kecemasan dan Ketidakpastian Dalam Menghadapi Wabah COVID-19 Management of Anxiety and Uncertainty in Facing. ETTISAL Journal of Communication, 5(2). https://doi.org/http://dx.doi.org/10.21111/ejoc.v5i2.4755

Febriani, N. W., \& Iqbal, F. (2015). Strategi Pengurangan Ketidakpastian dalam Sistem Komunikasi Interpersonal (Studi Fenomenologi pada Peserta On The Job Training Program Ke Jepang dari PT. Hitachi Construction Machinery Indonesia Periode Pemberangkatan Tahun 2009-2012). 08(02), 6580.

Gibbs, J. L., Ellison, N. B., \& Lai, C. H. (2011). First comes love, then comes google: An investigation of uncertainty reduction strategies and self-disclosure in online dating. Communication Research, 38(1), 70-100. https://doi.org/10.1177/0093650210377091

Haidar, A., Erickson, S. G., \& Champagne-Langabeer, T. (2020). Medical Students' Participation in Longitudinal Community Service During Preclerkship Years: A Qualitative Study on Experiences and Perceived Outcomes. Journal of Medical Education and Curricular Development, 7, 238212052093661. https://doi.org/10.1177/2382120520936610

Kemendikbud. (2020). No Title. 
Kholisin, K. (2014). Kecemasan Berbicara Ditinjau Dari Konsep Diri Dan Kecerdasan Emosional. Jurnal Ilmu Dakwah, 34(1), 77. https://doi.org/10.21580/jid.v34i1.65

Kriyantono, R. (2012). Teknik Praktis Riset Komunikasi: Disertai Contoh Praktis Riset Media. Public Reations, Advertising, Komunikasi Organisasi, Komunikasi Pemasaran (Edisi Pert). Kencana Prenada Media Group.

Littlejohn, S. W., Foss, K. A., \& Oetzel, J. G. (2017). Theories of Human Communication (11th ed.). Waveland Press, Inc.

Malestha, A., \& Kusumaningtyas, R. (2020). Pengurangan Ketidakpastian pada Pekerja Salon Tunarungu dalam Melayani Pelanggan Baru. Komuniti : Jurnal Komunikasi Dan Teknologi Informasi, 12(1), 5167. https://doi.org/10.23917/komuniti.v12i1.10651

Prihatsanti, U., Suryanto, S., \& Hendriani, W. (2018). Menggunakan Studi Kasus sebagai Metode Ilmiah dalam Psikologi. Buletin Psikologi, 26(2), 126. https://doi.org/10.22146/buletinpsikologi.38895

Primasari, W. (2014). Pengelolaan Kecemasan dan Ketidakpastian Diri Dalam Berkomunikasi Studi Kasus Mahasiswa Perantau UNISMA Bekasi. Jurnal Ilmu Komunikasi, 12(1), 26-38.

Rismayanti. (2018). Hambatan Komunikasi Yang Sering Dihadapi Dalam Sebuah Organisasi. Al-Hadi, $4(1), 825-834$.

Sugiyono. (2013). Metode Penelitian Kuantitatif, Kualitatif, dan $R \& D$. Alfabeta.

Syafnidawaty. (2020). Data Sekunder. https://raharja.ac.id/2020/11/08/data-sekunder/

West, R., \& Turner, L. H. (2018). Introducing Communication Theory Analysis and Application. In Making Sense of Messages.

WHO. (2020). No Title.

\section{Copyrights}

Copyright for this article is retained by the author(s), with first publication rights granted to the journal.

This is an open-access article distributed under the terms and conditions of the Creative Commons Attribution license (http://creativecommons.org/licenses/by/4.0/). 